\title{
The RAGE Trial \\ (Radial Arterial Graft in the Elderly)- A Pilot Study
}

\begin{abstract}
Use of radial artery (RA) as a second arterial conduit in Coronary Artery Bypass Grafting (CABG) is well established and appreciated for its higher long-term patency rate compared to vein grafts. This study tends to investigate if there are any detrimental consequences when it is used in elderly (aged 60 and above) population of Bangladesh. A total of 71 patients who received RA grafts at elective, isolated CABG operation were consecutively enrolled in this study from May 2018 to September 2019. 31 patients were in the Elderly group and 40 patients were in the Non-elderly group. The groups were compared for baseline characteristics and co-morbidities; preoperative techniques, findings, events and procedures; and postoperative outcomes or end-point variables inclusive of local complications related to RA harvesting wound. Elderly and Non-elderly groups had statistically different age $(p=0.000)$ and Society of Thoracic Surgery (STS) Score predicted mortality $(p=0.000)$. Operative techniques, events, findings and procedures were similar. Clinical outcomes were found to be similar with no statistical difference between the groups. Number of deaths also was not statistically different. There were no local complications related to RA harvesting wound in either of the two groups. Harvesting and grafting of radial artery in suitable patients, using meticulous "no-touch" technique and for ideal target coronary artery stenosis is as safe in the elderly patients as in the younger ones.
\end{abstract}

Zaman $\mathrm{T}^{1}$, Ali $\mathrm{MS}^{2}$, Rahman $\mathrm{S}^{3}$, Begum $\mathrm{M}^{4}$, Bhuiyan $\mathrm{MA}^{5}$

Key words: Radial Artery, CABG, Elderly.

CBMJ 2020 July: vol. 09 no. 02 P: 8-13

\section{Introduction}

There is nothing new to claim about the higher long-term patency of radial artery (RA) grafts over saphenous vein grafts, as conduits for CABG. ${ }^{1,2}$ It is a king, once crowned by Alain Carpentier in 1973, exiled after 2 years in 1975 with charges of intense vasospasm and graft occlusion, and then crowned again 15 years later in 1987 when fully patent radial grafts were found in repeat angiograms, 15 years after operation. $^{3-6}$ The key changes that have taken place in the harvesting \& preparation of radial artery nowadays from the past are(I) RA is harvested as a pedicle, including 2 satellite veins and the surrounding fatty tissue, using an atraumatic "no-touch" technique. During harvesting, direct handling of the RA is avoided. (II) Mechanical dilation of the graft has been replaced by pharmacological dilation with papaverine, a phosphodiesterase III inhibitor that enhances the nitric oxide pathway, minimizing endothelial damage and dysfunction, \& (III) In hopes of minimizing postoperative RA spasm, vasodilator therapy, most commonly with calcium channel blockers or nitrates, has been adopted. $^{7}$ Recently, the 2018 European Society of Cardiology and European Association for Cardio-Thoracic Surgery (ESC/EACTS) Guideline on Myocardial Revascularization has recommended

1. Dr. Tanveer Zaman, Associate Consultant of Cardiac Surgery, Dept. of Cardiac Surgery, Bangladesh Specialized Hospital Ltd. (BSH), Dhaka, Bangladesh.

2. Dr. Md. Shaukat Ali, Dept. of Cardiac Surgery, Bangladesh Specialized Hospital Ltd. (BSH), Dhaka, Bangladesh.

3. Dr. Shahidur Rahman, Dept. of Cardiac Surgery, Bangladesh Specialized Hospital Ltd. (BSH), Dhaka, Bangladesh.

4. Dr. Mahfuza Begum, Dept. of Cardiac Surgery, Ibrahim Cardiac Hospital \& Research Institute (ICHRI), Dhaka, Bangladesh.

5. Dr. Mohammad Ali Bhuiyan, Dept. of Cardiac Surgery, Bangladesh Specialized Hospital Ltd. (BSH), Dhaka, Bangladesh.

Address of correspondence:

Email: tanveerzaman@yahoo.com 
the use of radial artery over the saphenous vein in high-grade coronary artery stenosis with a Class IB recommendation. ${ }^{7-11}$

However, concerns over its use in the elderly patients with possible multiple comorbidities still remain. Though there have been multiple studies through retrospective analysis of various databases regarding the efficacy and safety of radial arterial grafts in the elderly population of both sexes, few are the number of prospective studies. ${ }^{12-17}$ With the increasing life expectancy of the Bangladeshi population, which is now 72.3 years (Bangladesh Bureau of Statistics, 2018), it is high time to ensure higher patency rates of our CABG conduits than before.

This prospective interventional single centric study tends to assess the efficacy and safety of using radial artery as a second arterial conduit in elderly Bangladeshi patients aged 60 years and above by comparing their outcome to those of patients below 60 years of age, undergoing Coronary Artery Bypass Grafting (CABG) operation.

\section{Methods}

Data were recorded prospectively of the CABG patients receiving Radial Artery grafts, operated between May 2018 and September 2019 at Bangladesh Specialized Hospital, Dhaka, Bangladesh. After excluding combined and emergency procedures, 71 patients were enrolled in The RAGE (Radial Arterial Graft in the Elderly) Trial. Of these 71 patients, 40 patients were younger than 60 years of age, enlisted in the Non-elderly group; while 32 patients were aged 60 years or above, enlisted in the Elderly group. Patients with a history of traumatic hand or forearm injuries were not considered for radial harvest. Also excluded were patients who had significant rheumatoid arthritis, Raynaud's, Dupuytren's, scleroderma, carpal tunnel syndromes, or documented subclavian stenosis affecting the donor arm. A pulse oximeter sensor was placed on the thumb of the planned donor extremity. Radial arteries were not used if base line room air oxygen saturation was less than $90 \%$. This oximeter also has a dynamic signal strength waveform graph. If the oxygen saturation exceeded 90\%, both ulnar and radial arteries were compressed at the wrist until the oximetric signal was lost. If release of the distal ulnar flow resulted in a return of the pulse oximeter signal to the base line value within 10 seconds, collateral flow was deemed adequate for radial usage.

All cases were operated off-pump electively unless conversion to on-pump was necessary.

Radial Artery was harvested as a pedicled graft along with paired vena commitantes and adjacent $5 \mathrm{~mm}$ strip of connective tissue as per the technique mentioned by Blitz et al. (2013). ${ }^{18}$ Even during operation, after clipping and electrocautery transection of all the branches, before division, the artery was temporarily clamped with a bulldog vascular clamp for a final assessment of ulnar collateral circulation demonstrated by digital pulse oximetric dynamic waveform and oxygen saturation. Immediately after operation, Diltiazem $15 \mathrm{mg}$ was started t.d.s orally (through nasogastric tube till extubation) and continued for 1 year.

For all statistical analysis, the level of significance was set at $0.05(p \leq 0.05)$.

\section{Results}

Baseline characteristics and co-morbidities were statistically similar between the groups (Table $-I)$, except age $(63.45 \pm 2.919$ versus $48.25 \pm 6.352, p=0.000)$ \& STS Score predicted mortality (median $0.673 \%$ versus $0.442 \%, p=0.000$ ), which were significantly higher in the Elderly group as expected. About half the patients in both groups suffered from diabetes mellitus. Hypertension was prevalent in $80 \%$ of patients. Coronary disease wise, $85 \%$ of all patients suffered from Triple Vessel Disease (TVD) and $77.5 \%$ of all patients were in CCS III or IV angina functional class. 
Table 1: Baseline Characteristics

\begin{tabular}{|c|c|c|c|}
\hline Variable & Elderly ( $\mathrm{n}=31$ ) & $\begin{array}{c}\text { Non-elderly } \\
(n=40)\end{array}$ & $P$ value \\
\hline Age $(\text { years })^{a}$ & $63.45 \pm 2.919$ & $48.25 \pm 6.352$ & 0.000 \\
\hline $\mathrm{BSA}(\mathrm{m} 2)^{\mathrm{a}}$ & $1.71 \pm 0.161$ & $1.72 \pm 0.145$ & 0.859 \\
\hline Female Sex ${ }^{c}$ & $5(16.1 \%)$ & $2(5.0 \%)$ & 0.227 \\
\hline Obese $(\mathrm{BMl}>30)^{\mathrm{C}}$ & $1(3.2 \%)$ & $2(5.0 \%)$ & 1.000 \\
\hline Serum Creatinine ${ }^{b}$ & 1.00 (IQR 0.86-1.20) & 0.96 (IQR $0.80-1.10$ ) & 0.286 \\
\hline History of $\mathrm{Ml}^{\mathrm{d}}$ & $19(61.3 \%)$ & $21(52.5 \%)$ & 0.459 \\
\hline Hypertension $^{d}$ & $29(93.5 \%)$ & $32(80.0 \%)$ & 0.104 \\
\hline Respiratory disease $^{c}$ & $3(9.7 \%)$ & $4(10.0 \%)$ & 1.000 \\
\hline Diabetes mellitus $^{d}$ & $17(54.8 \%)$ & $20(50.0 \%)$ & 0.686 \\
\hline Hypothyroidism $^{c}$ & $6(19.4 \%)$ & $4(10.0 \%)$ & 0.315 \\
\hline $\mathrm{PVD}^{\mathrm{C}}$ & $3(9.7 \%)$ & $1(2.5 \%)$ & 0.311 \\
\hline History of Renal Failure ${ }^{c}$ & $1(3.2 \%)$ & $1(2.5 \%)$ & 1.000 \\
\hline History of CVA/TIA & $2(6.5 \%)$ & $0(0 \%)$ & 0.187 \\
\hline History of $\mathrm{CCF}^{\mathrm{C}}$ & $3(9.7 \%)$ & $1(2.5 \%)$ & 0.311 \\
\hline $\begin{array}{l}\text { History of cardiogenic } \\
\text { shock }\end{array}$ & $1(3.2 \%)$ & $0(0.0 \%)$ & 0.437 \\
\hline Unstable Angina $^{c}$ & $4(12.9 \%)$ & $6(15.0 \%)$ & 0.801 \\
\hline Failed $\mathrm{PCl}^{\mathrm{C}}$ & $1(3.2 \%)$ & $4(10.0 \%)$ & 0.378 \\
\hline NYHA III/IV status ${ }^{d}$ & $24(77.4 \%)$ & $31(77.5 \%)$ & 0.994 \\
\hline $\operatorname{LVEF}(\%)^{\mathrm{a}}$ & $54.58 \pm 9.77$ & $56.80 \pm 9.16$ & 0.329 \\
\hline Impaired LVEF $(30-49 \%)^{d}$ & $8(25.8 \%)$ & $9(22.5 \%)$ & 0.746 \\
\hline Triple Vessel Disease ${ }^{d}$ & $29(93.5 \%)$ & $34(85.0 \%)$ & 0.452 \\
\hline$? 50 \%$ left main stenosis ${ }^{d}$ & $7(22.6 \%)$ & $9(22.5 \%)$ & 0.994 \\
\hline EuroSCOREII ${ }^{b}$ & $\begin{array}{c}1.12 \text { (IQR } 0.89 \text { - } \\
1.83) \\
\end{array}$ & 0.94 (IQR 0.75 - 1.48) & 0.338 \\
\hline STS Score $^{b}$ & $\begin{array}{c}0.673 \text { (IQR 0.554- } \\
1.015) \\
\end{array}$ & $\begin{array}{c}0.442 \text { (IQR } 0.333- \\
0.642) \\
\end{array}$ & 0.000 \\
\hline
\end{tabular}

a Data analyzed using Student's t test.

${ }^{b}$ Median and interquartile range (IQR) are given due to skewed distribution of data. Data analyzed using Mann-Whitney $\mathbf{U}$ test.

d Data analyzed using Fisher's exact test.

Data analyzed using Chi-square test.

The operative techniques, findings and procedures had no statistical difference between the groups. In almost all cases, at least one Internal Mammary Artery (IMA) was used, unless there was no significant LAD disease. All patients received at least 2 arterial grafts. The mean total number of grafts was similar (3.68 \pm 0.599 in the
Elderly versus $3.78 \pm 0.947$ in the Nonelderly, $p=0.618$ ). The average vessel diameter, number of conversions to onpump CABG, number of endartarectomy procedures failed to achieve a statistically significant difference between the Elderly and Non-elderly groups.

Table - II: Operative variables

\begin{tabular}{|c|c|c|c|}
\hline Variable & Elderly ( $n=31)$ & $\begin{array}{c}\text { Non-elderly } \\
(n=40)\end{array}$ & $P$ value \\
\hline IMA used $^{c}$ & $30(96.8)$ & $39(97.5)$ & 1.000 \\
\hline Total number of grafts ${ }^{\mathrm{a}}$ & $3.68 \pm .599$ & $3.78 \pm .947$ & 0.618 \\
\hline Number of arterial grafts ${ }^{b}$ & 2.0 (IQR $2.0-2.0)$ & $2.0($ IQR 2.0 - 2,0) & 0.350 \\
\hline $\begin{array}{l}\text { Average vessel } \\
\text { size(mm })^{b}\end{array}$ & $\begin{array}{c}1.63 \text { (IQR } 1.50 \text { - } \\
1.75)\end{array}$ & 1.59 (IQR $1.50-1.73$ ) & 0.669 \\
\hline $\begin{array}{c}\text { Incomplete } \\
\text { Revascularization }^{c}\end{array}$ & $1(3.2 \%)$ & $2(5.0 \%)$ & 1.000 \\
\hline IABP use ${ }^{c}$ & $0(0.0 \%)$ & $1(2.5 \%)$ & 1.000 \\
\hline Conversion to $\mathrm{CPB}^{\mathrm{C}}$ & $1(3.2 \%)$ & $2(5.0 \%)$ & 1.000 \\
\hline Endarterectomy $^{c}$ & $3(9.7 \%)$ & $3(7.5 \%)$ & 1.000 \\
\hline
\end{tabular}

${ }^{a}$ Data analyzed using Student's $t$ test.

b Median and interquartile range (IQR) are given due to skewed distribution of data. Data analyzed using Mann-Whitney $\mathrm{U}$ test.

\section{${ }^{\mathrm{C}}$ Data analyzed using Fisher's exact test.}

The postoperative outcome variables or study end points showed no statistical difference between the two groups. Although median ventilation time was statistically significantly higher in the Elderly group (12.75 hrs versus $9.00 \mathrm{hrs}, \mathrm{p}=0.02$ ), but when a cutoff value of 24 hours was applied as per standard definition of prolonged ventilation, both the groups showed no statistical difference.

The most important finding pertinent to this study was that, although there were 3 cases of sternal or leg wound complication in each of the groups, there was not a single case of radial harvest site infection/ hematoma/ dehiscence, hand grip weakness or forearm/ hand paresthesia in any of the groups 
Table - III: Postoperative adverse clinical outcomes

\begin{tabular}{|c|c|c|c|}
\hline Variable & Elderly $(n=31)$ & $\begin{array}{c}\text { Non-elderly } \\
(n=40)\end{array}$ & \begin{tabular}{|c|}
$P$ \\
value
\end{tabular} \\
\hline $\begin{array}{l}\text { Neurological } \\
\text { Complication }^{c}\end{array}$ & $0(0.0 \%)$ & $0(0.0)$ & 1.000 \\
\hline Reopening $^{\mathrm{C}}$ & $0(0.0 \%)$ & $1(2.6 \%)$ & 1.000 \\
\hline Cardiac arrest $^{c}$ & $0(0.0 \%)$ & $3(7.5 \%)$ & 0.252 \\
\hline Perioperative $\mathrm{Ml}^{\mathrm{C}}$ & $0(0.0 \%)$ & $2(5.0 \%)$ & 0.501 \\
\hline Renal failure/ Dialysis ${ }^{c}$ & $1(3.2 \%)$ & $0(0.0 \%)$ & 0.443 \\
\hline $\begin{array}{l}\text { Respiratory } \\
\text { complication }^{d}\end{array}$ & $7(22.6 \%)$ & $5(12.8 \%)$ & 0.282 \\
\hline ARDS $^{c}$ & $2(6.5)$ & $1(2.6)$ & 0.580 \\
\hline High inotrope support ${ }^{c}$ & $6(19.4 \%)$ & $3(7.5 \%)$ & 0.165 \\
\hline Gl complication $^{\circ}$ & $2(6.5 \%)$ & $0(0.0 \%)$ & 0.193 \\
\hline Arrhythmia $^{d}$ & $6(19.4 \%)$ & $8(20.0 \%)$ & 0.946 \\
\hline $\begin{array}{l}\text { Sternal/ Leg Wound } \\
\text { Complication }{ }^{c}\end{array}$ & $3(9.7 \%)$ & $3(7.7 \%)$ & 1.000 \\
\hline $\begin{array}{l}\text { Forearm Wound } \\
\text { complication }^{c}\end{array}$ & $0(0.0 \%)$ & $0(0.0 \%)$ & 1.000 \\
\hline Hand Grip Weakness ${ }^{c}$ & $0(0.0 \%)$ & $0(0.0)$ & 1.000 \\
\hline Forearm Paraesthesis ${ }^{c}$ & $0(0.0 \%)$ & $0(0.0 \%)$ & 1.000 \\
\hline Ventilation time $(h r)^{b}$ & $\begin{array}{r}12.75(\text { IQR } \\
5.23-16.81)\end{array}$ & $\begin{array}{c}9.00(\text { IQR } \\
4.92-13.00)\end{array}$ & 0.020 \\
\hline $\begin{array}{l}\text { Prolonged ventilation } \\
\qquad 24 \mathrm{hr}^{\mathrm{c}}\end{array}$ & $2(6.5 \%)$ & $0(0.0 \%)$ & 0.193 \\
\hline $\begin{array}{l}\text { Postoperative hospital } \\
\text { stay (days) }\end{array}$ & $\begin{array}{l}8.00(\mathrm{IQR} \\
7.00-8.00)\end{array}$ & $\begin{array}{l}7.00(\text { IQR } \\
7.00-8.00)\end{array}$ & 0.315 \\
\hline $\begin{array}{l}\text { Prolonged Postop length } \\
\text { of stay }>8 \text { days }{ }^{d}\end{array}$ & $5(16.1 \%)$ & $5(13.2 \%)$ & 0.745 \\
\hline 30-day mortality ${ }^{c}$ & $1(3.2 \%)$ & $2(5.0 \%)$ & 1.000 \\
\hline $\begin{array}{c}\text { Readmission within } 30 \\
\text { days }^{c}\end{array}$ & $0(0.0 \%)$ & $0(0.0 \%)$ & 1.000 \\
\hline
\end{tabular}

${ }^{a}$ Data analyzed using Student's $t$ test.

$\mathrm{b}_{\text {Median and interquartile range (IQR) are }}$ given due to skewed distribution of data. Data analyzed using Mann-Whitney U test.

${ }^{c}$ Data analyzed using Fisher's exact test.

$\mathrm{d}_{\text {Data analyzed using Chi-square test. }}$
There were 4 cases of death in the whole study. 3 were 30-day mortality and 1 was a death 42 days after surgery in a patient who had been discharged. Among the 30-day mortality cases, 1 patient was in the Elderly group who died 19 days after surgery from ARDS. This patient was a case of triple vessel disease with CCS Class - III Angina for 7 years on the background of $\mathrm{Ml}$ (Anteroseptal) 2 years back, cardiac arrest 4 months back, TIA 5 years back, LVEF $45 \%$, Grade-II diastolic dysfunction, LV anterior wall hypokinesia, mild pulmonary hypertension (PASP $45 \mathrm{mmHg}$ ), diabetes mellitus (on insulin), chronic kidney disease (S.Creatinine $1.9 \mathrm{mg} / \mathrm{dL}$ ), with hypertension. The patient that died 42 days after surgery also falls in the Elderly group. This patient had persistent serous chest drainage during the immediate post-operative period. Cytology, biochemistry, cultures and clinical parameters indicated that the drain was transudative. Hence after a course of corticosteroid, when the drainage became scantier the drain tubes were removed on 9th POD and the patient discharged on 10th POD. However, the patient got readmitted a month later with the complaints of persistent cough, breathlessness, anorexia and fever. $\mathrm{He}$ was diagnosed as bilateral parapneumonic pleural effusion with septicemia, with unstable sternum, with severe hyponatremia. He died 4 days after admission.

2 Patients died in the Non-elderly group. Of them, one died on the 2nd POD who was on very high inotropic support due to low output syndrome. This patient was near morbid obese (BMI 37. 9) with critical left main stenosis (80\%) with triple vessel disease with hypertension and sleep apnea (on regular home BIPAP), LVEF 64\%. He started having ventricular tachycardia with hypotension during operation. Hence, operation was converted to on-pump CABG. But weaning from bypass was very difficult and the patient deteriorated progressively in the ICU. Death of the second patient in the Non-elderly group was very much unexpected. This was a case of triple vessel 
disease with DM (on insulin) and hypertension. He had an LV ejection fraction of $50 \%$. The patient was in his 4 th POD, about to be transferred to his cabin, when he suddenly collapsed. Sudden onset VT \& VF followed by sudden cardiac arrest ensued. While giving CPR, he was immediately reopened, cardiopulmonary bypass was established, an additional vein graft to LAD was given, IABP was started, yet the patient could not be weaned from bypass.

\section{Discussion:}

The present study demonstrates that radial graft functions are not affected by age as claimed by Onorati et al. (2007); neither do chances of hand ischemia or radial harvest wound complications increase in the elderly as claimed by Greene et al. (2001). ${ }^{15,19}$ While it is not the intention of this study to compare between Bilateral Internal Mammary Artery (BIMA) versus Left Internal Mammary Artery plus Radial Artery (LIMA + RA) use, yet in patients who are at known risk of sternal wound infection, judiciously using the radial artery for high-grade stenosis instead of Right Internal Mammary Artery (RIMA) maybe a better alternative with predictable consequences, sacrificing a few percentages of long-term patency rate. Use of radial artery requires careful selection of patients, meticulous harvesting technique and scrupulous target coronary identification. While there is no easy way to preoperatively predict state of sternal vascularity if both the IMAs are harvested, state of hand vascularity is easily predictable if the radial is harvested.

\section{Conclusion:}

Benedetto et al. (2013) published a study showing that the survival benefit or radial artery was no longer present in patients older than 70 years. ${ }^{20}$ However, considering better healing in forearm wounds than leg wounds due to higher vascularity and less fat in the upper limb, we recommend that RA grafts be used in all ages for all suitable coronaries, so long there is no contraindication in harvesting it. The current transradial (TR) approach for coronary angiography leaves surgeons with no option to choose between the two RAs during CABG. If the virgin upper limb is not suitable, an RA graft plan has to be abandoned altogether. There is now comprehensive evidence that TR coronary angiography and intervention cause severe morphologic and functional damage to the intervened RA, which could undoubtedly impact its function as a graft in CABG. Whether these damages are permanent or how long they take to completely heal, warrants further studies. Hence, we recommend that in case of a failure at transradial approach in one hand, the other hand should not be attempted. While performing a TR approach, efforts should be made to minimize damage to the RA, such as through choosing the smallest possible catheter along with use of highdose heparin to minimize intimal denudation and vessel thrombosis.

\section{References:}

1. Possati G, Gaudino M, Prati F, et al. Longterm results of the radial artery used for myocardial revasculariza-tion. Circulation. 2003; 108: 1350-4.

2. Deb $S$, Cohen $E A$, Singh $S K$, Une $D$, Laupacis A, Fremes SE, Investigators $R$. Radial artery and saphenous vein patency more than 5 years after coronary artery bypass surgery: results from RAPS (Radial Artery Patency Study), J Am Coll Cardiol, 2012, vol.60 (1): 28-35.

3. Carpentier A, Guermonprez JL, Deloche A, Frechette $C$, DuBost $C$. The aorta-tocoronary radial artery bypass graft: a technique avoiding pathological changes in grafts. Ann Thorac Surg. 1973;16:111-121.

4. Curtis JJ, Stoney WS, Alford WC Jr, Burrus GR, Thomas CS Jr. Intimal hyperplasia. A cause of radial artery aortocoronary bypass graft failure. Ann Thorac Surg. 1975;20:62835.

5. Fisk RL, Brooks $\mathrm{CH}$, Callaghan JC, Dvorkin $J$. Experience with the Radial Artery Graft for Coronary Artery Bypass. Ann Thorac Surg. 1976; 21 (6):513-518. 
6. Acar $C$, Jebara VA, Portoghese $M$, et al. Revival of the radial artery for coronary artery bypass grafting. Ann Thorac Surg. 1992;54:652- 60.

7. Verma S, Szmitko PE, Weisel RD, Bonneau $D$, Latter $D$, Errett $L$, LeClerc Y, Fremes SE. Should radial arteries be used routinely for coronary artery bypass grafting? Circulation. 2004; 110: e40-e46.

8. Gaudino $M$, Benedetto $U$, Fremes $S$, BiondiZoccai G, Sedrakyan A, Puskas JD, Angelini $G D$, Buxton B, Frati G, Hare DL, Hayward $P$, Nasso G, Moat N, Peric M, Yoo KJ, Speziale G, Girardi LN, Taggart DP; RADIAL Investigators. Radial-artery or saphenousvein grafts in coronary-artery bypass surgery. N Engl J Med 2018; 378:2069-2077.

9. Taggart $D P$, Altman $D G$, Flather $M$, Gerry $S$, Gray A, Lees B, Benedetto U, ART (Arterial Revascularization Trial) Investigators. Associations between adding a radial artery graft to single and bilateral internal thoracic artery grafts and outcomes: Insights from the Arterial Revascularization Trial. Circulation. 2017;136:454-463.

10. Yamasaki M, Deb S, Tsubota H, Moussa F, Kiss A, Cohen EA, Radhakrishnan S, Dubbin $J$, Ko D, Schwartz L, Fremes SE, Radial Artery Patency Study Investigators. Comparison of radial artery and saphenous vein graft stenosis more than 5 years after coronary artery bypass grafting. Ann Thorac Surg. 2016;102:712-719.

11. Desai ND, Cohen EA, Naylor CD, Fremes SE, Radial Artery Patency Study Investigators. A randomized comparison of radial-artery and saphenous-vein coronary bypass grafts. N Engl J Med. 2004;351:23022309.

12. Gaudino $M$, Tondi $P$, Benedetto $U$, Milazzo $V$, Flore R, Glieca F, Ponziani FR, Luciani N, Girardi LN, Crea F, Massetti M. Radial artery as a coronary artery bypass conduit: 20-year results. J Am Col I Cardiol. 2016;68:603-610.

13. Modine T, Al-Ruzzeh S, Mazrani W, Azeem $F$, Bustami M, Ilsley C, Amrani M. Use of radial artery graft reduces the morbidity of coronary artery bypass graft surgery in patients aged 65 years and older. Ann Thorac Surg. 2002;74(4):1144-7.
14. Habib RH, Abou-Arraj NE, Schwann TA. Radial artery as a second arterial graft in the elderly and both sexes. Ann Cardiothorac Surg. 2013;2(4):453-457. doi:10.3978/j.issn.2225 319X.2013.06.05.

15. Onorati F, Pezzo F, Comi MC, et al. Radial artery graft function is not affected by age. $J$ Thorac Cardiovasc Surg 2007; 134:1112-20.

16. Whitaker JF, Passos PHC, Ramalho GM, Muniz AJ, Castro Pimentel R, Lopes Lourdes $J B$, Borges AF, Miana AA. The use of the radial artery as the second choice for arterial graft in patients over 70 years of age. Braz J Cardiovasc Surg. 2005;20: 58-62.

17. Habib RH, Schwann TA, Engoren M. Late effects of radial artery versus saphenous vein grafting in patients aged 70 years or older. Ann Thorac Surg 2012;94:1478-84.

18. Blitz A, Osterday RM, Brodman RF. Harvesting the radial artery. Ann Cardiothorac Surg. 2013;2(4):533-542. doi:10.3978/j.issn.2225-319X.2013.07.10.

19. Greene MA, Malias MA. Arm complications after radial artery procurement for coronary bypass operation. Ann Thorac Surg. 2001;72:126-128.

20. Benedetto U, Codispoti M. Age cutoff for the loss of survival benefit from use of radial artery in coronary artery bypass grafting. J Thorac Cardiovasc Surg 2013;146:1078- 84. 